\title{
Profile of Rural Women Involved in the Income Generating Activities of Self-Help Groups in Jaipur District of Rajasthan, India
}

\author{
K. Asha and I.M. Khan* \\ Department of Extension Education, SKNCOA(SKNAU), Jobner-Jaipur, Rajasthan, India \\ *Corresponding author
}

\section{A B S T R A C T}

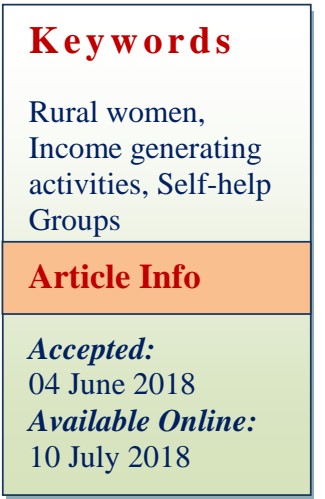

Women constitute half of the humanity, even contributing two-third of world's work hours. Rural women in India constitute 77.00 per cent of the female population. They share abundant responsibility and perform a wide spectrum of duties; even then they suffer from being both economically and socially invisible. It was found that Majority of the rural women involved in the income generating activities of Self-Help Groups were having middle age (21 to 40 years), belonged to general caste, were involved in business, were educated up to middle school, were having no land, had medium material possession, were from Joint family, belonged to large families, having more than 5 members, were having medium socio-economic status, were having medium social participation, were married, were having medium annual income (Rs. 116870.82 to Rs. 180545.84), had undergone no training and were having medium mass media exposure. And no correlation between the profile and type of SHG was observed. It was suggested that a comparative analysis of the empowerment of women those involved in income generating activities with women not involved in income generating activities may be conducted, the areas of the research can be extended and sufficiently large sample of rural women may be studied.

\section{Introduction}

Women constitute half of the humanity, even contributing two-third of world's work hours. Women are regarded as the "better half" of the society and at par with the men. But in reality, our society is still male dominated and women are not treated as equal partners both inside and outside the four walls of the house. In fact they are treated as weak and dependent on men. As such, Indian women enjoy an unfavorable status in society. Empowerment is a multi-dimensional process, which enable women or group of women to realize their full identity and power in all spheres of life (Surekharao and Rajamanamma, 1999).

Self- help groups have emerged as one of the major strategies for women's empowerment and various schemes of the Government of India have shown that strong women's groups could contribute substantially to the development and convergence of services and activities It is worthwhile to mention that Department of Women and Child Development (DWCD), Government of Rajasthan is the largest promoter of SHG in the state (Anonymous, 2010). The present 
study is likely to provide valuable information to the government and non-government agencies about the extent of empowerment of the rural women through income generating activities of the Self-Help Groups and the factors influencing the empowerment. The study has been designed to focus on the contribution of socio-economic characteristics of rural women towards the extent of empowerment. This helps in identifying methods that enhance the extent of empowerment of rural women. The constraints that are experienced by the rural women and suggestions for empowerment will be of immense help for policy makers and women development programme initiators to plan the future programmes most effectively

\section{Materials and Methods}

Study was conducted in Jaipur district of Rajasthan, as Jaipur district is one among the pioneer districts in Rajasthan to start income generating activities (Micro-credit activities) in the form of women self-help groups in rural areas. There are various Self-Help Group Promoting Institutes (SHPIs) in the district who are actively involved in the empowerment of women. Also, Jaipur district comes under the best performing districts in terms of SHG-bank linkage (Khandal, 2014). Viratnagar and Jhotwara were selected purposely for the study, due to having maximum number of SHGs in Jaipur District. From each selected Panchayat samiti, three villages were selected randomly consisting of total 6 villages for study purpose. From each selected village two SHGs one run by DWCD and another run by NGO running from last 3-5 years and actively involved in different income generating activities consisting a total of 6 SHGs from DWCD and 6 SHGs from NGOs were selected randomly. From each SHG, 10 rural women, actively involved in the income generating activities from last 3-5 years, were selected randomly. Thus, the overall sample consisted of 120 respondents comprising 60 rural women from SHGs run by DWCD and 60 rural women from SHGs run by NGOs.

An interview schedule consisting of measuring devices of dependent and independent variables along with the face data of rural women involved in the income generating activities of Self- Help Groups was prepared. The data were collected by the investigator by personally interviewing the rural women in local dialect with the help of structured interview schedule.

The attributes like caste, occupation, education level, size of land holding, house type, farm power, farm implements, material possession, type and size of family, social participation and socio-economic status were measured by the scale developed by $G$. Trivedi (1963) with slight modifications as suggested by experts. The age of rural women was measured using absolute scores, whereas the variables like marital status, income of the family and mass media exposure were measured with the help of the schedules developed by the investigator after getting experts opinion. Thereafter, data were tabulated, analyzed and inferences were drawn after subjecting the data to statistical analysis which led to the following major findings.

\section{Results and Discussion}

The data in Table 1 revealed that Majority of the rural women involved in the income generating activities of Self-Help Groups $(77.50 \%)$ were having middle age (21 to 40 years). Majority of the of the rural women involved in the income generating activities of Self-Help Groups run by DWCD (70.00 \%) and NGOs $(85.00 \%)$ belonged to middle age group. There was a significant agreement between the age of rural women involved in the income generating activities of Self-Help Groups run by DWCD and NGOs. 
The data in Table 2 revealed that Majority of the rural women $(87.50 \%)$ belonged to the category of General caste followed by backward community. Majority of the rural women involved in the income generating activities of Self-Help Groups run by DWCD $(80.00 \%)$ and NGOs (95.00\%) belonged to general caste. There was no significant agreement between the caste of rural women involved in the income generating activities of Self-Help Groups run by DWCD and NGOs.

The data in Table 3 revealed that Majority of the rural women involved in the income generating activities of Self-Help Groups (73.33\%) were involved in business followed by Dairy $(15.00 \%)$ and service $(6.67 \%)$. Majority of the rural women involved in the income generating activities of Self-Help Groups run by DWCD (88.33\%) were involved in business followed by service $(11.67 \%)$, while majority of rural women involved in the income generating activities of Self-Help Groups run by NGOs, (58.33\%) were involved in business followed by Dairy $(30.00 \%)$ and service + business $(6.67 \%)$. There was a significant agreement between the occupation of rural women involved in the income generating activities of Self-Help Groups run by DWCD and NGOs.

The data in Table 4 revealed that Majority of the rural women involved in the income generating activities of Self-Help Groups $(38.33 \%)$ were educated upto middle school followed by primary school $(35.00 \%)$ and Graduate (12.5\%). About 40.00 percent of the rural women involved in the income generating activities of Self-Help Groups run by DWCD were educated upto middle school and equal percentage $(40.00 \%)$ of them were educated upto primary school, while in case of the rural women involved in the income generating activities of Self-Help Groups run by NGOs, about 36.67 per cent rural women were educated upto middle school. There was a significant agreement between the education level of the rural women involved in the income generating activities of Self-Help Groups run by DWCD and NGOs

The data in Table 5 revealed that Majority of the rural women involved in the income generating activities of Self-Help Groups $(94.17 \%)$ were having no land followed by $1.67 \%$ rural women having 1-2.5 hectares of land and $1.67 \%$ rural women were having 8.1-10 hectares of land. Majority of the rural women involved in the income generating activities of Self-Help Groups run by DWCD $(95.00 \%)$ and NGOs (93.32\%) were having no land. There was a non-significant agreement between the land holdings of rural women involved in the income generating activities of Self-Help Groups run by DWCD and NGOs.

The data in Table 6 revealed that Majority of the rural women involved in the income generating activities of Self-Help Groups $(72.50 \%)$ were having medium material possession. Majority of the rural women involved in the income generating activities of Self-Help Groups run by DWCD (76.67 \%) and NGOs $(68.33 \%)$ were found having medium material possession. There was a significant agreement between the material possessions of rural women involved in the income generating activities of Self-Help Groups run by DWCD and NGOs.

The data in Table 7 revealed that Majority of the rural women involved in the income generating activities of Self-Help Groups $(92.50 \%)$ were from Joint family. Majority of the rural women involved in the income generating activities of Self-Help Groups run by DWCD (91.67\%) and NGOs (93.33\%) were from Joint family. There was a nonsignificant agreement between the family type of rural women involved in the income generating activities of Self-Help Groups run 
by DWCD and NGOs. The data in Table 8 revealed that Majority of the Rural women involved in the income generating activities of Self-Help Groups (89.17\%) belonged to big families having more than 5 members. Majority of the rural women involved in the income generating activities of Self-Help Group run by DWCD $(91.67 \%)$ and NGOs (86.67\%) belonged to big families having more than 5 members. There was a non significant agreement between the family size of rural women involved in the income generating activities of Self-Help Groups run by DWCD and NGOs. The data in Table 9 revealed that Majority of the rural women involved in the income generating activities of Self-Help Groups $(75.83 \%)$ were found having medium socio-economic status. Majority of the rural women involved in the income generating activities of Self-Help Groups run by DWCD (91.67 \%) and NGOs
$(60.00 \%)$ were found having medium socioeconomic status. There was a significant agreement between the socio-economic status of rural women involved in the income generating activities of Self-Help Groups run by DWCD and NGOs.

The data in Table 10 revealed that Majority of the rural women involved in the income generating activities of Self-Help Groups $(85.00 \%)$ were having medium social participation. Majority of the rural women involved in the income generating activities of Self-Help Groups run by DWCD (83.33\%) and NGOs $(86.67 \%)$ were having medium social participation. There was a nonsignificant agreement between the social participation of rural women involved in the income generating activities of Self-Help Groups run by DWCD and NGOs.

Table.1 Distribution of rural women involved in income generating activities of self-help groups according to their age

$\mathbf{N}=\mathbf{1 2 0}$

\begin{tabular}{|c|c|c|c|c|c|c|c|}
\hline \multirow[t]{2}{*}{$\begin{array}{l}\text { S. } \\
\text { No. }\end{array}$} & \multirow[t]{2}{*}{ Age categories } & \multicolumn{2}{|c|}{$\begin{array}{l}\text { Rural women of } \\
\text { SHGs run by DWCD } \\
(\mathrm{N}=60)\end{array}$} & \multicolumn{2}{|c|}{$\begin{array}{l}\text { Rural women of } \\
\text { SHGs run by NGO } \\
(\mathrm{N}=60)\end{array}$} & \multicolumn{2}{|c|}{$\begin{array}{l}\text { Total } \\
\text { respondents } \\
(\mathrm{N}=120)\end{array}$} \\
\hline & & $\mathbf{F}$ & Per cent & $\mathbf{F}$ & Per cent & $\mathbf{F}$ & Per cent \\
\hline 1. & $\begin{array}{l}\text { Young age } \\
\text { (Below 20.86score) }\end{array}$ & 8 & 13.33 & 8 & 13.33 & 16 & 13.33 \\
\hline 2. & $\begin{array}{l}\text { Middle Age }(20.86 \\
\text { to39.70 score })\end{array}$ & 42 & 70.00 & 51 & 85.00 & 93 & 77.50 \\
\hline 3. & $\begin{array}{l}\text { Old age (Above } 39.70 \\
\text { score) }\end{array}$ & 10 & 16.67 & 1 & 1.67 & 11 & 9.17 \\
\hline - & Total & 60 & 100.00 & 60 & 100.00 & 120 & 100.00 \\
\hline
\end{tabular}


Table.2 Distribution of rural women involved in income generating activities of Self-Help Groups according to their caste

\begin{tabular}{|c|c|c|c|c|c|c|c|}
\hline \multirow{3}{*}{ S.No. } & \multirow{3}{*}{ Caste categories } & & \multicolumn{2}{|c|}{$N=120$} \\
\hline & & \multicolumn{2}{|c|}{$\begin{array}{l}\text { Rural women of SHGs run by } \\
\text { DWCD }(\mathrm{N}=60)\end{array}$} & \multicolumn{2}{|c|}{$\begin{array}{l}\text { Rural women of SHGs run } \\
\text { by NGO }(\mathrm{N}=60)\end{array}$} & \multicolumn{2}{|c|}{$\begin{array}{l}\text { Total } \\
\text { respondents } \\
(\mathrm{N}=120)\end{array}$} \\
\hline & & $\mathbf{F}$ & Per cent & $\mathbf{F}$ & Per cent & $\mathbf{F}$ & Per cent \\
\hline 1. & Scheduled tribe & 0 & 0.00 & 0 & 0.00 & 0 & 0.00 \\
\hline 2. & Scheduled caste & 0 & 0.00 & 0 & 0.00 & 0 & 0.00 \\
\hline 3. & $\begin{array}{l}\text { Special backward } \\
\text { caste }\end{array}$ & 0 & 0.00 & 0 & 0.00 & 0 & 0.00 \\
\hline 4. & $\begin{array}{l}\text { Other backward } \\
\text { caste }\end{array}$ & 12 & 20.00 & 3 & 5.00 & 15 & 12.50 \\
\hline 5. & General caste & 48 & 80.00 & 57 & 95.00 & 105 & 87.50 \\
\hline 6. & Other caste & 0 & 0.00 & 0 & 0.00 & 0 & 0.00 \\
\hline & Total & 60 & 100.00 & 60 & 100.00 & 120 & 100.00 \\
\hline
\end{tabular}
$\chi^{2}=6.171$ (Non- significant) $\quad$ d.f $=5$

Tabulated value of $\chi^{2}$ at 5 per cent level of significance $=11.070$

Table.3 Distribution of rural women involved in income generating activities of Self-Help Groups according to their occupation

$\mathbf{N}=120$

\begin{tabular}{|c|c|c|c|c|c|c|c|}
\hline \multirow[t]{2}{*}{$\begin{array}{l}\text { S.N } \\
\text { o. }\end{array}$} & \multirow[t]{2}{*}{$\begin{array}{l}\text { Occupation } \\
\text { categories }\end{array}$} & \multicolumn{2}{|c|}{$\begin{array}{l}\text { Rural women of SHGs } \\
\text { run by DWCD }(\mathrm{N}=60)\end{array}$} & \multicolumn{2}{|c|}{$\begin{array}{l}\text { Rural women of SHGs run } \\
\text { by NGO }(\mathrm{N}=60)\end{array}$} & \multicolumn{2}{|c|}{$\begin{array}{l}\text { Total respondents } \\
\quad(\mathrm{N}=120)\end{array}$} \\
\hline & & F & Per cent & $\mathbf{F}$ & Per cent & $\mathbf{F}$ & Per cent \\
\hline 1. & Labour & 0 & 0.00 & 0 & 0.00 & 0 & 0.00 \\
\hline 2. & Caste occupation & 0 & 0.00 & 0 & 0.00 & 0 & 0.00 \\
\hline 3. & Dairy & 0 & 0.00 & 18 & 30.00 & 18 & 15.00 \\
\hline 4. & Agriculture & 0 & 0.00 & 0 & 0.00 & 0 & 0.00 \\
\hline 5. & Business & 53 & 88.33 & 35 & 58.33 & 88 & 73.33 \\
\hline 6. & Service & 7 & 11.67 & 1 & 1.67 & 8 & 6.67 \\
\hline 7. & Service+ Business & 0 & 0.00 & 4 & 6.67 & 4 & 3.33 \\
\hline 8. & Service + Dairy & 0 & 0.00 & 2 & 3.33 & 2 & 1.67 \\
\hline & Total & 60 & 100.00 & 60 & 100.00 & 120 & 100.00 \\
\hline
\end{tabular}

$\chi^{2}=25.56 * *(* *$ Significant at 1 per cent level of significance)

Tabulated value of $\chi^{2}$ at 1 per cent level of significance $=18.475$

d.f $=7$

Tabulated value of $\chi^{2}$ at 5 per cent level of significance $=14.067$ 
Table.4 Distribution of rural women involved in income generating activities of self-help groups according to their education level

\begin{tabular}{|c|c|c|c|c|c|c|c|}
\hline \multirow[t]{2}{*}{ S.No. } & \multirow[t]{2}{*}{$\begin{array}{l}\text { Education level } \\
\text { categories }\end{array}$} & \multicolumn{2}{|c|}{ Rural women of SHGs run by DWCD $(\mathrm{N}=60)$} & \multicolumn{2}{|c|}{ Rural women of SHGs run by NGO $(\mathrm{N}=60)$} & \multicolumn{2}{|c|}{$\begin{array}{l}\text { Total respondents } \\
\quad(\mathrm{N}=120)\end{array}$} \\
\hline & & $\mathbf{F}$ & Per cent & $\mathbf{F}$ & Per cent & $\mathbf{F}$ & Per cent \\
\hline 1. & Illiterate & 0 & 0.00 & 0 & 0.00 & 0 & 0.00 \\
\hline 2. & Can sign only & 0 & 0.00 & 0 & 0.00 & 0 & 0.00 \\
\hline 3. & Can read only & 0 & 0.00 & 0 & 0.00 & 0 & 0.00 \\
\hline 4. & Can read and write & 0 & 0.00 & 0 & 0.00 & 0 & 0.00 \\
\hline 5. & Primary School & 24 & 40.00 & 18 & 30.00 & 42 & 35.00 \\
\hline 6. & Middle school & 24 & 40.00 & 22 & 36.67 & 46 & 38.33 \\
\hline 7. & High School & 10 & 16.67 & 0 & 0.00 & 10 & 8.33 \\
\hline 8. & Higher secondary & 2 & 3.33 & 5 & 8.33 & 7 & 5.84 \\
\hline 9. & Graduate & 0 & 0.00 & 15 & 25.00 & 15 & 12.50 \\
\hline 10. & Above graduate & 0 & 0.00 & 0 & 0.00 & 0 & 0.00 \\
\hline & Total & 60 & 100.00 & 60 & 100.00 & 120 & 100.00 \\
\hline
\end{tabular}

$\chi^{2}=27.23 * *\left(* *\right.$ Significant at 1 per cent level of significance) $\quad$ d.f $=9$; Tabulated value of $\chi^{2}$ at 1 per cent level of significance $=21.666$

Tabulated value of $\chi^{2}$ at 5 per cent level of significance $=16.919$

Table.5 Distribution of rural women involved in income generating activities of self-help groups according to their land holding

\begin{tabular}{|c|c|c|c|c|c|c|c|}
\hline \multirow[t]{2}{*}{ S.No. } & \multirow[t]{2}{*}{$\begin{array}{l}\text { Land holding } \\
\text { categories }\end{array}$} & \multicolumn{2}{|c|}{ Rural women of SHGs run by DWCD $(\mathrm{N}=60)$} & \multicolumn{2}{|c|}{$\begin{array}{l}\text { Rural women of SHGs run by NGO } \\
\qquad(\mathrm{N}=60)\end{array}$} & \multicolumn{2}{|c|}{$\begin{array}{l}\text { Total respondents } \\
(\mathbf{N}=120)\end{array}$} \\
\hline & & $\mathbf{F}$ & Per cent & $\mathbf{F}$ & Per cent & $\mathbf{F}$ & Per cent \\
\hline 1. & No land & 57 & 95.00 & 56 & 93.32 & 113 & 94.17 \\
\hline 2. & Less than 1 ha & 0 & 0.00 & 1 & 1.67 & 1 & 0.83 \\
\hline 3. & $1-2.5$ ha & 1 & 1.66 & 1 & 1.67 & 2 & 1.67 \\
\hline 4. & $2.6-4.0$ ha & 0 & 0.00 & 1 & 1.67 & 1 & 0.83 \\
\hline 5. & 4.1-6.0 ha & 1 & 1.67 & 0 & 0.00 & 1 & 0.83 \\
\hline 6. & $6.1-8.0$ ha & 0 & 0.00 & 0 & 0.00 & 0 & 0.00 \\
\hline 7. & $8.1-10$ ha & 1 & 1.67 & 1 & 1.67 & 2 & 1.67 \\
\hline 8. & More than 10 ha & 0 & 0.00 & 0 & 0.00 & 0 & 0.00 \\
\hline & Total & 60 & 100.00 & 60 & 100.00 & 120 & 100.00 \\
\hline
\end{tabular}

$\chi^{2}=3.009 \quad$ (Non-significant) $\quad$ d.f $=7$; Tabulated value of $\chi^{2}$ at 5 per cent level of significance $=14.067$ 
Table.6 Distribution of rural women involved in income generating activities of self-help groups according to their material possession

\begin{tabular}{|c|c|c|c|c|c|c|c|}
\hline \multirow[t]{2}{*}{ S.No. } & \multirow[t]{2}{*}{ Material possession categories } & \multicolumn{2}{|c|}{ Rural women of SHGs run by DWCD $(\mathrm{N}=60)$} & \multicolumn{2}{|c|}{ Rural women of SHGs run by NGO $(\mathrm{N}=60)$} & \multicolumn{2}{|c|}{$\begin{array}{l}\text { Total respondents } \\
\qquad(\mathrm{N}=120)\end{array}$} \\
\hline & & $\mathbf{F}$ & Percent & $\mathbf{F}$ & Percent & $\mathbf{F}$ & Percent \\
\hline 1. & Low (less than 36.98 score) & 10 & 16.66 & 5 & 8.34 & 15 & 12.50 \\
\hline 2. & Medium (36.98 to 43.98 score) & 46 & 76.67 & 41 & 68.33 & 87 & 72.50 \\
\hline \multirow[t]{2}{*}{3.} & High (more than 43.98 score) & 4 & 6.67 & 14 & 23.33 & 18 & 15.00 \\
\hline & $\ldots$ Total & 60 & 100.00 & 60 & 100.00 & 120 & 100.00 \\
\hline
\end{tabular}

$\bar{x}=40.48 \quad \sigma=3.5 \chi^{2}=7.509^{*} \quad$ d.f $=2 \quad$ (*Significant at 5 per cent level of significance); Tabulated value of $\chi^{2}$ at 5 per cent level of significance $=5.991$

Table.7 Distribution of rural women involved in income generating activities of Self-Help Groups according to their type of family

\begin{tabular}{|c|c|c|c|c|c|c|c|}
\hline \multirow{2}{*}{ S.No. } & \multirow{2}{*}{$\begin{array}{c}\text { Family type } \\
\text { categories }\end{array}$} & \multicolumn{2}{|c|}{ DWCD respondents $(\mathrm{N}=60)$} & \multicolumn{2}{|c|}{ NGO respondents $(\mathrm{N}=60)$} & \multicolumn{2}{|c|}{ Total respondents $(\mathrm{N}=120)$} \\
\hline & & $\mathbf{F}$ & Per cent & $\mathbf{F}$ & Per cent & $\mathbf{F}$ & Per cent \\
\hline 1. & Nuclear family & 5 & 8.33 & 4 & 6.67 & 9 & 7.50 \\
\hline & Total & 60 & 100.00 & 60 & 100.00 & 120 & 100.00 \\
\hline
\end{tabular}

$\chi^{2}=0.1201$ (Non- significant) $\quad$ d.f $=1 ;$ Tabulated value of $\chi^{2}$ at 5 per cent level of significance $=3.84$

Table.8 Distribution of rural women involved in income generating activities of self-help groups according to their size of family

$\mathrm{N}=120$

\begin{tabular}{|c|c|c|c|c|c|c|c|}
\hline \multirow[t]{2}{*}{ S.No } & \multirow[t]{2}{*}{ Family size categories } & \multicolumn{2}{|c|}{ Rural women of SHGs run by DWCD $(\mathrm{N}=60)$} & \multicolumn{2}{|c|}{ Rural women of SHGs run by $\mathrm{NGOs(N=60)}$} & \multicolumn{2}{|c|}{$\begin{array}{c}\text { Total respondents } \\
(\mathrm{N}=120)\end{array}$} \\
\hline & & $\mathbf{F}$ & Per cent & $\mathbf{F}$ & Per cent & $\mathbf{F}$ & Per cent \\
\hline 1. & $\begin{array}{l}\text { Small family } \\
\text { (Upto } 5 \text { members) }\end{array}$ & 5 & 8.33 & 8 & 13.33 & 13 & 10.83 \\
\hline 2. & $\begin{array}{l}\text { Big family } \\
\text { (More than } 5 \text { members) }\end{array}$ & 55 & 91.67 & 52 & 86.67 & 107 & 89.17 \\
\hline & Total & 60 & 100.00 & 60 & 100.00 & 120 & 100.00 \\
\hline
\end{tabular}

$\chi^{2}=0.7764$ (Non- significant) $\quad$ d.f $=1$; Tabulated value of $\chi^{2}$ at 5 per cent level of significance $=5.991$ 
Table.9 Distribution of rural women involved in income generating activities of Self-Help Groups according to their socio-economic status

\section{$\mathbf{N}=\mathbf{1 2 0}$}

\begin{tabular}{|c|c|c|c|c|c|c|c|}
\hline \multirow[t]{2}{*}{ S.No. } & \multirow[t]{2}{*}{$\begin{array}{l}\text { Socio-economic status } \\
\text { categories }\end{array}$} & \multicolumn{2}{|c|}{ Rural women of SHGs run by DWCD $(\mathrm{N}=60)$} & \multicolumn{2}{|c|}{ Rural women of SHGs run by NGOs $(\mathrm{N}=60)$} & \multicolumn{2}{|c|}{$\begin{array}{l}\text { Total respondents } \\
\qquad(\mathrm{N}=120)\end{array}$} \\
\hline & & $\mathbf{F}$ & Per cent & $\mathbf{F}$ & Per cent & $\mathbf{F}$ & Per cent \\
\hline 1. & Low (less than56.78 score) & 5 & 8.33 & 4 & 6.67 & 9 & 7.50 \\
\hline 2. & $\begin{array}{l}\text { Medium } \\
\text { (56.78 to } 75.47 \text { score) }\end{array}$ & 55 & 91.67 & 36 & 60.00 & 91 & 75.83 \\
\hline 3. & High (Above 75.47 score) & 0 & 0.00 & 20 & 33.33 & 20 & 16.67 \\
\hline & Total & 60 & 100.00 & 60 & 100.00 & 120 & 100.00 \\
\hline
\end{tabular}
$\overline{\mathrm{X}}=66.13 \quad \sigma=9.34 \chi^{2}=24.078^{* *} \quad$ d.f $=2$

(**Significant at 1 per cent level of significance)

Tabulated value of $\chi^{2}$ at 1 per cent level of significance $=9.210$

Tabulated value of $\chi^{2}$ at 5 per cent level of significance $=5.991$

Table.10 Distribution of rural women involved in income generating activities of Self-Help Groups according to their social participation

$\mathrm{N}=\mathbf{1 2 0}$

\begin{tabular}{|c|c|c|c|c|c|c|c|}
\hline \multirow[t]{2}{*}{$\begin{array}{r}\text { S.N } \\
\text { o. }\end{array}$} & \multirow[t]{2}{*}{$\begin{array}{l}\text { Social participation } \\
\text { categories }\end{array}$} & \multicolumn{2}{|c|}{$\begin{array}{l}\text { Rural women of SHGs run by DWCD } \\
\qquad(\mathrm{N}=60)\end{array}$} & \multicolumn{2}{|c|}{$\begin{array}{l}\text { Rural women of SHGs run by NGOs } \\
\qquad(\mathrm{N}=60)\end{array}$} & \multicolumn{2}{|c|}{$\begin{array}{l}\text { Total respondents } \\
\qquad(\mathrm{N}=120)\end{array}$} \\
\hline & & $\mathbf{F}$ & Per cent & $\mathbf{F}$ & Per cent & $\mathbf{F}$ & Per cent \\
\hline 1. & $\begin{array}{l}\text { Low (less than } 1.97 \\
\text { score) }\end{array}$ & 0 & 0.00 & 0 & 0.00 & 0 & 0.00 \\
\hline 2. & $\begin{array}{l}\text { Medium (1.97 to } 5.06 \\
\text { score) }\end{array}$ & 50 & 83.33 & 52 & 86.67 & 102 & 85.00 \\
\hline 3. & $\begin{array}{l}\text { High (Above } 5.06 \\
\text { score) }\end{array}$ & 10 & 16.67 & 8 & 13.33 & 18 & 15.00 \\
\hline & Total & 60 & 100.00 & 60 & 100.00 & 120 & 100.00 \\
\hline
\end{tabular}

$\overline{\mathrm{x}}=3.52 \quad \sigma=1.54 \quad \chi^{2}=0.261$ (Non-significant) $\quad$ d.f $=2$

Tabulated value of $\chi^{2}$ at 5 per cent level of significance $=5.991$ 
Table.11 Distribution of rural women involved in income generating activities of self-help groups according to their marital status

\begin{tabular}{|c|c|c|c|c|c|c|c|}
\hline \multirow[t]{2}{*}{ S.No } & \multirow{2}{*}{$\begin{array}{c}\text { Marital } \\
\text { status } \\
\text { categories }\end{array}$} & \multicolumn{2}{|c|}{ Rural women of SHGs run by DWCD $(\mathrm{N}=60)$} & \multicolumn{2}{|c|}{ Rural women of SHGs run by NGOs $(\mathrm{N}=60)$} & \multicolumn{2}{|c|}{$\begin{array}{l}\text { Total respondents } \\
\qquad(\mathrm{N}=120)\end{array}$} \\
\hline & & $\mathbf{F}$ & Per cent & $\mathbf{F}$ & Per cent & $\mathbf{F}$ & Per cent \\
\hline 1. & Unmarried & 0 & 0.00 & 0 & 0.00 & 0 & 0.00 \\
\hline 2. & Married & 50 & 83.33 & 56 & 93.33 & 106 & 88.33 \\
\hline 3. & Widow & 10 & 16.67 & 4 & 6.67 & 14 & 11.67 \\
\hline 4. & Separated & 0 & 0.00 & 0 & 0.00 & 0 & 0.00 \\
\hline & Total & 60 & 100.00 & 60 & 100.00 & 120 & 100.00 \\
\hline
\end{tabular}

$\chi^{2}=2.911$ (Non- significant) $\quad$ d.f $=3$

Tabulated value of $\chi^{2}$ at 5 per cent level of significance $=7.815$

Table.12 Distribution of rural women involved in the income generating activities of self-help groups according to the annual income of the family

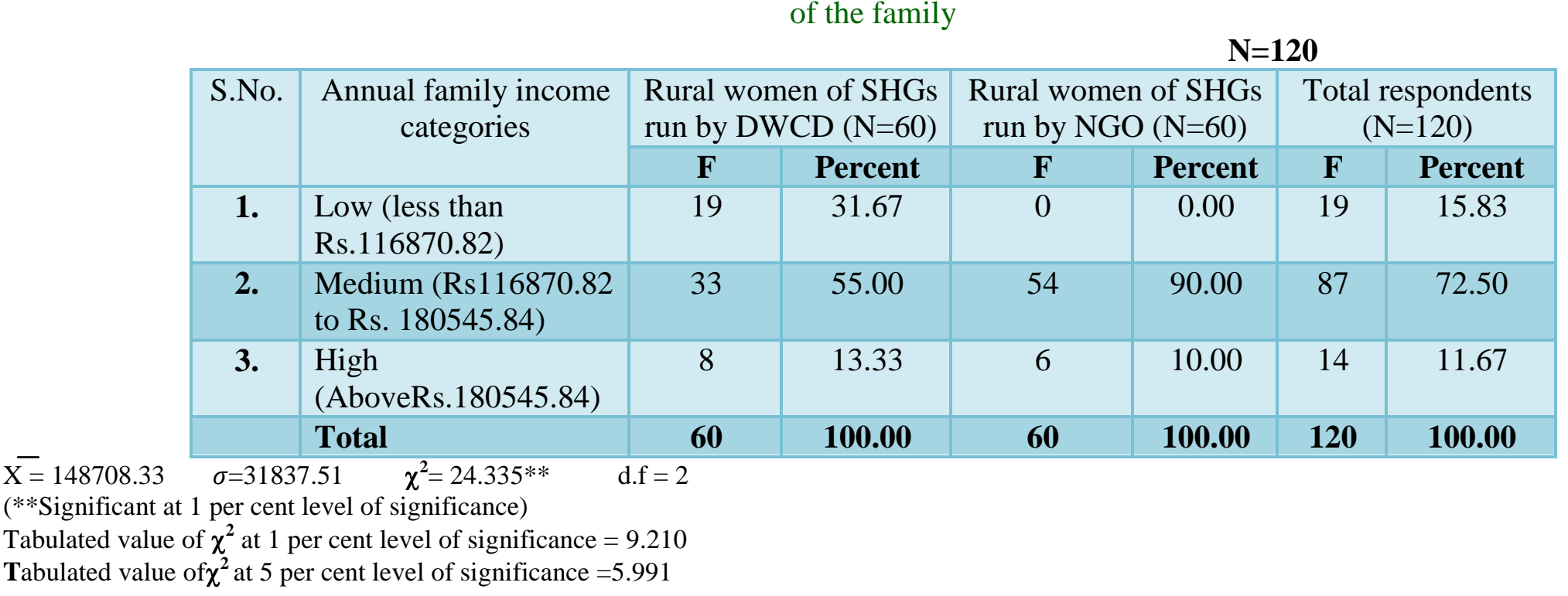


Table.13 Distribution of rural women involved in income generating activities of self-help groups according to the number of trainings undergone

\section{$\mathbf{N}=120$}

\begin{tabular}{|c|c|c|c|c|c|c|c|}
\hline \multirow[t]{2}{*}{$\begin{array}{l}\text { S. } \\
\text { No. }\end{array}$} & \multirow[t]{2}{*}{$\begin{array}{c}\text { Number of trainings } \\
\text { categories }\end{array}$} & \multicolumn{2}{|c|}{ Rural women of SHGs run by DWCD $(\mathrm{N}=60)$} & \multicolumn{2}{|c|}{ Rural women of SHGs run by NGO $(\mathrm{N}=60)$} & \multicolumn{2}{|c|}{$\begin{array}{l}\text { Total respondents } \\
\qquad(\mathrm{N}=120)\end{array}$} \\
\hline & & $\mathbf{F}$ & Per cent & $\mathbf{F}$ & Per cent & $\mathbf{F}$ & Per cent \\
\hline 1. & No training & 40 & 66.66 & 20 & 33.33 & 60 & 50.00 \\
\hline 2. & One training & 10 & 16.67 & 40 & 66.67 & 50 & 41.67 \\
\hline 3. & Two and above trainings & 10 & 16.67 & 0 & 0.00 & 10 & 8.33 \\
\hline & Total & 60 & 100.00 & 60 & 100.00 & 120 & 100.00 \\
\hline
\end{tabular}

$\chi^{2}=13.33 * *(* *$ Significant at 1 per cent level of significance)

Tabulated value of $\chi^{2}$ at 1 per cent level of significance $=9.210$

Tabulated value of $\chi^{2}$ at 5 per cent level of significance $=5.991$

Table.14 Distribution of rural women involved in income generating activities of self-help groups according to the number of $\mathbf{N}=\mathbf{1 2 0}$

\begin{tabular}{|c|c|c|c|c|c|c|c|}
\hline \multirow{3}{*}{ S.No. } & \multicolumn{7}{|l|}{$N=120$} \\
\hline & \multirow[t]{2}{*}{$\begin{array}{c}\text { Training days } \\
\text { categories }\end{array}$} & \multicolumn{2}{|c|}{ Rural women of SHGs run by DWCD $(\mathrm{N}=60)$} & \multicolumn{2}{|c|}{ Rural women of SHGs run by NGOs $(\mathrm{N}=60)$} & \multicolumn{2}{|c|}{$\begin{array}{l}\text { Total respondents } \\
\qquad(\mathrm{N}=120)\end{array}$} \\
\hline & & $\mathbf{F}$ & Per cent & $\mathbf{F}$ & Per cent & $\mathbf{F}$ & Per cent \\
\hline 1. & Nil & 40 & 66.66 & 20 & 33.33 & 60 & 50.00 \\
\hline 2. & Upto5 man days & 10 & 16.67 & 40 & 66.67 & 50 & 41.67 \\
\hline 3. & More than 5 man days & 10 & 16.67 & 0 & 0.00 & 10 & 8.33 \\
\hline & Total & 60 & 100.00 & 60 & 100.00 & 120 & 100.00 \\
\hline
\end{tabular}

$\chi^{2}=13.33 * *(* *$ Significant at 1 per cent level of significance)

Tabulated value of $\chi^{2}$ at 1 per cent level of significance $=9.210$

Tabulated value of $\chi^{2}$ at 5 per cent level of significance $=5.991$ 
Table.15 Distribution of rural women involved in income generating activities of self-help groups according to the mass media exposure

\begin{tabular}{|c|c|c|c|c|c|c|c|}
\hline \multirow[t]{2}{*}{ S.No. } & \multirow[t]{2}{*}{$\begin{array}{l}\text { Mass media exposure } \\
\text { categories }\end{array}$} & \multicolumn{2}{|c|}{ Rural women of SHGs run by DWCD $(\mathrm{N}=60)$} & \multicolumn{2}{|c|}{ Rural women of SHGs run by NGOs $(\mathrm{N}=60)$} & \multicolumn{2}{|c|}{$\begin{array}{l}\text { Total respondents } \\
\qquad(\mathrm{N}=120)\end{array}$} \\
\hline & & $\mathbf{F}$ & Percent & $\mathbf{F}$ & Percent & $\mathbf{F}$ & Percent \\
\hline 1. & Low (less than 2.17 score) & 15 & 25.00 & 9 & 15.00 & 24 & 20.00 \\
\hline 2. & Medium (2.17 to 6.69 score) & 45 & 75.00 & 36 & 60.00 & 81 & 67.50 \\
\hline \multirow[t]{2}{*}{3.} & High (more than 6.69 score) & 0 & 0.00 & 15 & 25.00 & 15 & 12.50 \\
\hline & Total & 60 & 100.00 & 60 & 100.00 & 120 & 100.00 \\
\hline & $\begin{array}{l}\mathrm{x}=\overline{4} .43 \quad \sigma=2.26 \quad \text { d.f }= \\
\chi^{2}=17.50^{* *}(* * \text { Significant at } 1 \text { per } \\
\text { Tabulated value of } \chi^{2} \text { at } 5 \text { per cent } \\
\text { Tabulated value of } \chi^{2} \text { at } 5 \text { per cent }\end{array}$ & $\begin{array}{l}2 \\
\text { cent level of si } \\
\text { level of signific } \\
\text { level of signific }\end{array}$ & & & & & \\
\hline
\end{tabular}


The data in Table 11 revealed that Majority of the rural women involved in the income generating activities of Self-Help Groups $(88.33 \%)$ were married while only 11.66 per cent of them were widow. Majority of the rural women involved in the income generating activities of Self-Help Groups run by DWCD (83.33\%) and NGOs (93.33\%), were married. There was a non-significant agreement between the marital status of rural women involved in the income generating activities of Self-Help Groups run by DWCD and NGOs.

The data in Table 12 revealed that Majority of the rural women involved in the income generating activities of Self-Help Groups $(72.50 \%)$ were having medium annual income (Rs116870.82 to Rs180545.84), whereas 15.83 per cent of the respondents were having low annual income (less than Rs 116870.82). Majority of the rural women involved in the income generating activities of Self- Help Groups run by DWCD (55.00\%) and NGOs $(90.00 \%)$ were having medium annual income. There was a significant agreement between the income of the rural women involved in the income generating activities of Self-Help Groups run by DWCD and NGOs.

The data in Table 13 revealed that Majority of the rural women involved in the income generating activities of Self-Help Groups $(50.00 \%)$ had undergone no training, whereas 41.67 per cent of them had undergone one training. Majority of the rural women involved in the income generating activities of SHGs run by DWCD (66.67 \%) had undergone no training whereas in case of the rural women involved in the income generating activities of SHGs run by NGOs, 66.67 percent of them had undergone one training. There was a significant agreement between the 'Number of trainings undergone' by rural women involved in the income generating activities of Self-Help Groups run

\section{by DWCD and NGOs.}

The data in Table 14 revealed that Majority of the rural women involved in the income generating activities of Self-Help Groups $(50.00 \%)$ had undergone no training followed by the rural women $(41.67 \%)$ who had undergone training for 1 to 5 mandays. Majority $(66.66 \%)$ of the rural women involved in the income generating activities of SHGs run by DWCD had not undergone training for a single day, whereas in case of rural women involved in the income generating activities of SHGs run by NGOs, majority $(66.67 \%)$ of the respondents had undergone training for 1-5 man days. There was a significant agreement between the 'Number of training days' of rural women involved in the income generating activities of Self-Help Groups run by DWCD and NGOs.

The data in Table 15 revealed that Majority of the rural women involved in the income generating activities of Self-Help Groups $(67.50 \%)$ were having medium mass media exposure, whereas 20.00 per cent of them were having low mass media exposure. Majority of the rural women involved in the income generating activities of Self-Help Groups run by DWCD (75.00 \%) and NGOs $(60.00 \%)$ were having medium mass media exposure. There was a significant agreement between the mass media exposure of rural women involved in the income generating activities of Self-Help Groups run by DWCD and NGOs.

\section{References}

Bharathamma, G.U. (2005). "Empowerment of rural women through income generating activities in Gadag District on Northern Karnataka.' M.Sc. Thesis, University of Agricultural Sciences, Dharwad.

Haque,M., Sahariya, K.K. and Khuman L.S. 
(2014). "Poultry Entrepreneur of SHG Members After bank Linkage against Inflation in Darrang and Kamrup Districts of Assam". Abstract: $7^{\text {th }}$ National Extension Education Congress on "Translational Research - Extension for sustainable Small Farm Development".08-11 November,2014

Padala. (2011). "Effect of self help groups in economic empowerment of rural women in Andhra Pradesh." Journal of Research in Peace, Gender and Development. 1(3):101-110

Rahman, Rahman M.I., Uddin M.M., Alam, A.B.M.S. and Kamaly, M.B. (2012). "Empowerment of rural women through participation in Income generating activities for maintaining livelihood." Journal of Socio-economic Research and Development,9(6):14091417.

Rewani, S.K., Mahto, V.K., Oraon, J. and Pandey, A.K. (2015). "Economic empowerment of women through livestock based entrepreneurial activities of self-help groups". Abstract:, National seminar on
"Extension Innovations and methodologies for market-led Agricultural Growth and Development" 26-28 February 2015

Singh,A., Sharma,S.K, Henry,C and Rathore, R. (2014). "Constraints Encountered by Women Member in Operating Various Enterprises in SHGs". Abstract: $7^{\text {th }}$ National Extension Education Congress on "Translational Research - Extension for sustainable Small Farm Development".08-11 November,2014

Singh, O.R. (2001). "Education and women's empowerment." Social Welfare, 48(1): 35-36

Sivasiya, M.D. (2010). "Empowerment of farm women through Self-Help Groups in Ajmer District of Rajasthan." M.Sc. (Agri.) Thesis, Swami Keshawanand Rajasthan Agricultural University, Bikaner

Victoria, N.S. and Someshwar, K. (1998).DWCRA: "A hope of light for women's development in rural areas." Kurukshetra, 46(3): 7-19.

\section{How to cite this article:}

Asha, K. and Khan, I.M. 2018. Profile of Rural Women Involved in the Income Generating Activities of Self-Help Groups in Jaipur District of Rajasthan, India. Int.J.Curr.Microbiol.App.Sci. 7(07): 241-253. doi: https://doi.org/10.20546/ijcmas.2018.707.029 